Tohoku J. Exp. Med., 2003, 201, 23-27

\title{
Pharmacological Mechanism in Slip-Down Behavior of Mice
}

\author{
Yutaka Masuda, Minoru Suzuki, ${ }^{1}$ Takaubu Takemura, ${ }^{1}$ Junya Sugawara, ${ }^{1}$ \\ Naxin Guo, ${ }^{2}$ Yang Liu, ${ }^{2}$ Yoshinikio Kawarada, ${ }^{2}$ Tetsuo Shimizu ${ }^{1}$ and \\ Toshiniro Sugiyama ${ }^{2}$ \\ Psychosomatic Division, ${ }^{1}$ Department of Neuropsychiatry, ${ }^{2}$ Department of \\ Biochemistry, Akita University School of Medicine, Akita 010-8543
}

Masuda, Y., Suzuki, M., Takemura, T., Sugawara, J., Guo, N., Liu, Y., Kawarada, Y., Shimizu, T. and Sugiyama, T. Pharmacological Mechanism in Slip-Down Behavior of Mice. Tohoku J. Exp. Med., 2003, 201 (1), 23-27Slip-down from a raised platform was previously found in mice treated with morphine, and this behavior was also recognized in mice treated with a monoamine releaser methamphetamine. Pharmacological examination on the slip-down indicated that the behavior was induced by receptor stimulations by $\mathrm{D}_{2}$ agonist PPHT and 5HT-2 agonist DOI. In mice treated with PPHT, antagonists of $\mathrm{D}_{1}, \alpha_{2}, 5 \mathrm{HT}-2$ and opioid mu and kappa suppressed the behavior. In mice treated with DOI, antagonists of $\mathrm{D}_{1}, \alpha_{2}, 5 \mathrm{HT}-1 \mathrm{~A}, 5 \mathrm{HT}-3$ and opioid mu and delta suppressed the behavior. These present findings suggest that the slip-down was mainly induced by opioid mu receptor activity regulated with monoamine activities. When the slip-down is considered as an anxious behavior, it may be also suggested that the anxiety induced by 5 -HT activities furthermore stimulated the behavior via the other opioid receptor activities.— slip-down behavior; mice; anxiety; opioid receptor; neurotransmitter activities

(C) 2003 Tohoku University Medical Press

It was previously reported that morphine induces an abnormal behavior, slip-down from a raised platform, on mice (Hui and Roberts 1975). We occasionally recognized that mice treated with a monoamine releaser methamphetamine (MAP) also showed the behavior. We have been very interested in relations of opioid receptor activities and the other neurotransmitter receptor activities in the behavior. In this paper, we investigate the pharmacological mechanism of the behavior.

\section{MATERIALS AND METHODS}

\section{Animals}

Male ddY mice, 8 weeks-old (Japan SLC, Inc., Shizuoka) were prepared. Each 5 of them were housed in a plastic cage $(338 \times 140 \times 225$ $\mathrm{mm}$ ) with free access to food (CE-7: Clea Japan Co., Tokyo) and water in a tapping plastic bottle. The animal room was kept at $21-25^{\circ} \mathrm{C}$ with 50-60\% humidity and illuminated from $7: 00$ to $19: 00$. All of the experiments were

Received June 9, 2003; revision accepted for publication August 28, 2003.

Address for reprints : Yutaka Masuda, Psychosomatic Division, Department of Neuropsychiatry, Akita University School of Medicine, 1-1-1 Hondo, Akita 010-8543, Japan. 
carried out under the control of the Ethics Committee for Animal Experiments of Akita University School of Medicine.

\section{Method detecting the slip-down and the effect of $M A P$}

MAP was purchased from Dainippon Seiyaku Co. (Osaka) and was prepared with water. A raised platform having $10 \mathrm{~cm}$ diameter and $20 \mathrm{~cm}$ height was prepared. Five mice in a cage were intraperitoneally injected with 1000,100 or $10 \mu \mathrm{g} / \mathrm{kg}$ of MAP, or $100 \mu \mathrm{l}$ of physiological saline (PS) as a control. Twenty minutes after the injection, the mice were individually placed on the platform and the slipdown from the platform was investigated for 5 minutes.

Effects of antagonists on the slip-down of mice treated with MAP

Antagonists, SCH-23390 $\left(\mathrm{D}_{1}\right)$, sulpiride $\left(\mathrm{D}_{2}\right)$, prazosin $\left(\alpha_{1}\right)$, yohimbine $\left(\alpha_{2}\right)$, propranolol $(\beta)$, NAN190 (5-HT1A), ketamserin (5-HT2) and LY-278, 584 (5-HT3) were purchased from Sigma Co. (St. Louis, MO, USA) and were prepared with water. A group of 5 mice were intraperitoneally injected with 100,10 or $1 \mu \mathrm{g} /$ $\mathrm{kg}$ of one of the antagonists, or $100 \mu \mathrm{l}$ of PS as a control. Twenty minutes after the injection, these groups of mice were intraperitoneally treated with $1 \mu \mathrm{g} / \mathrm{kg}$ of MAP, and then, the slip-down of these mice was individually investigated 20 minutes after the MAP treatment.

\section{Agonists inducing the slip-down}

Agonists, SKF-38393 $\left(\mathrm{D}_{1}\right)$, PPHT hydrochloride $\left(\mathrm{D}_{2}\right)$, methoxamine $\left(\alpha_{1}\right)$, clonidine $\left(\alpha_{2}\right)$, isoproterenol $(\beta)$, 8-Hydroxy-DPAT (5-HT1A), DOI hydrochloride (5-HT2) and 2-methylserotonin (5-HT3) were also purchased from Sigma Co. and were prepared with water. One hundred, 50 or $25 \mu \mathrm{g} / \mathrm{kg}$ of one of the agonists, or $100 \mu \mathrm{l}$ of PS as a control was injected to a group of five mice, and then, the slip-down of these mice was individually investigated.
Effects of antagonists on the slip-down of mice treated with PPHT

One hundred, 10 or $1 \mu \mathrm{g} / \mathrm{kg}$ of the antagonist of $\mathrm{D}_{1}, \alpha_{1}, \alpha_{2}, \beta, 5$-HT1A, 5 -HT2 or 5 -HT3, 1000,100 or $10 \mu \mathrm{g} / \mathrm{kg}$ of antagonist of opioid mu, delta or kappa (naloxone, ICI 174864, norbinaltorphimine; Sigma Co.), or $100 \mu 1$ of PS as a control was injected to a group of five mice. Twenty minutes after the injection, $100 \mu \mathrm{g} / \mathrm{kg}$ of PPHT was treated to these mice, and then, the slip-down of the mice was individually investigated.

Effects of antagonists on mice treated with DOI

One hundred, 10 or $1 \mu \mathrm{g} / \mathrm{kg}$ of the antagonist of $\mathrm{D}_{1}, \mathrm{D}_{2}, \alpha_{1}, \alpha_{2}, \beta, 5$-HT1A or 5-HT3, 1000 , 100 or $10 \mu \mathrm{g} / \mathrm{kg}$ of the antagonist of opioid mu, delta or kappa, or $100 \mu 1$ of PS as a control was injected to a group of five mice. Twenty minutes after the injection, $100 \mu \mathrm{g} / \mathrm{kg}$ of DOI was treated to these mice, and then, the slipdown of the mice was individually investigated.

\section{Statistical analysis}

The analysis was performed with Fisherman's exact probability test.

\section{RESULTS}

MAP induced the slip-down at the dose of $1 \mathrm{mg} / \mathrm{kg}$ (Table 1). Stereotyped behaviors: continuous sniffing and circling were not found in the mice treated with MAP at any doses. The slip-down induced by MAP was suppressed by the $\mathrm{D}_{1}, \mathrm{D}_{2}, \alpha_{2}, 5$-HT1A, 5 -HT2 or 5 -HT3 receptor antagonists (Table 2). $\mathrm{D}_{2}$ agonist PPHT $100 \mu \mathrm{g} / \mathrm{kg}$ and 5-HT2 agonist DOI 100 $\mu \mathrm{g} / \mathrm{kg}$ induced the slip-down on mice, but the other agonists did not (Table 3). The slip-down induced by PPHT was suppressed by the $\mathrm{D}_{1}, \alpha_{2}$, 5-HT2, opioid mu or kappa antagonist (Table 4). The slip-down induced by DOI was suppressed by the $\mathrm{D}_{1}, \alpha_{2}, 5$-HT1A, 5 -HT3, opioid mu or delta antagonist (Table 5). 
TABLE 1. Effect of methamphetamine on the slip-down behavior

Mice showing the ship-down Dose $(\mu \mathrm{g} / \mathrm{kg})$ of methamphetamine

\begin{tabular}{cccc}
\hline 1000 & 100 & 10 & (Control) PS \\
\hline $5^{*}$ & 0 & 0 & 0
\end{tabular}

A group of five mice were intrapeitoneally injected with methamphetamine solution at these doses. Twenty minutes after the treatments, mice were individually placed on a platform and were investigated the slip-down.

PS; physiological saline.

$* p=0.0396<0.05$ compared to the control (Fisher's exact probability test).

TABLE 2. Effects of antagonists on the slipdown behavior induced by methamphetamine

\begin{tabular}{llll}
\hline \multirow{2}{*}{ Antagonist } & \multicolumn{3}{c}{$\begin{array}{c}\text { Mice showing the ship-down } \\
\text { Dose }(\mu \mathrm{g} / \mathrm{kg})\end{array}$} \\
\cline { 2 - 4 } & 100 & 10 & 1 \\
\hline $\mathrm{D}_{1}$ : SCH-23390 & $0^{*}$ & $0^{*}$ & 5 \\
$\mathrm{D}_{2}$ : Sulpiride & $0^{*}$ & $0^{*}$ & 5 \\
$\alpha_{1}$ : Prazosin & 5 & 5 & 5 \\
$\alpha_{2}$ : Yohimbine & $0^{*}$ & $0^{*}$ & 5 \\
$\beta$ : Propranolol & 5 & 5 & 5 \\
5-HT1A: NAN 190 & $0^{*}$ & 5 & 5 \\
5-HT2: Ketanserin & $0^{*}$ & 5 & 5 \\
5-HT3: LY-278, 584 & $0^{*}$ & 5 & 5 \\
(Control) PS & & 5 & \\
\hline
\end{tabular}

A group of five mice were intrapeitoneally injected with each antagonist, and also treated with $1 \mathrm{mg} / \mathrm{kg}$ of methamphetamine 20 minutes after the injection. PS, physiological saline. ${ }^{*} p=0.0396<0.05$ compared to the control (Fisher's exact probability test).

\section{DISCUSSION}

Behaviorally, the slip-down is different from the increasing of ambulation of mice, because the ambulation induced by MAP increases on the place with the diameter of 15 $\mathrm{cm}$ and above (Hirabayashi et al. 1991). Falldown in cliff avoidance reaction test looks like the slip-down, but the behavior was not found in mice treated with MAP (Yoshida et al. 2000). As behaviors induced by MAP are affected by
TABle 3. Agonists inducing the slip-down

\begin{tabular}{lccc}
\hline \multirow{1}{*}{ Agonist } & \multicolumn{3}{c}{$\begin{array}{c}\text { Mice showing the ship-down } \\
\text { Dose }(\mu \mathrm{g} / \mathrm{kg})\end{array}$} \\
\cline { 2 - 4 } & 100 & 50 & 25 \\
\hline $\mathrm{D}_{1}$ : SKF-38393 & 0 & 0 & 0 \\
$\mathrm{D}_{2}$ : PPHT & $5^{*}$ & 0 & 0 \\
$\alpha_{1}$ : Methoxamine & 0 & 0 & 0 \\
$\alpha_{2}$ : Clonidine & 0 & 0 & 0 \\
$\beta$ : Isoproterenol & 0 & 0 & 0 \\
5-HT1A: DPAT & 0 & 0 & 0 \\
5-HT2: DOI & $5^{*}$ & 0 & 0 \\
5-HT3: 2-methylserotonin & 0 & 0 & 0 \\
(Control) PS & & 0 & \\
\hline
\end{tabular}

Each of agonists was treated to a group of five mice.

PS; physiological saline.

${ }^{*} p=0.0396<0.05$ compared to the control

(Fisher's exact probability test).

TABLE 4. Effects of antagonists on the slipdown behavior induced by $D_{2}$ agonist PPHT

\begin{tabular}{lcll}
\hline \multirow{2}{*}{ Antagonist } & \multicolumn{3}{c}{$\begin{array}{c}\text { Mice showing the ship-down } \\
\text { Dose }(\mu \mathrm{g} / \mathrm{kg})\end{array}$} \\
\cline { 2 - 4 } & 100 & 10 & 1 \\
\hline $\mathrm{D}_{1}$ & $0^{*}$ & 5 & 5 \\
$\alpha_{1}$ & 5 & 5 & 5 \\
$\alpha_{2}$ & $0^{*}$ & $0^{*}$ & 5 \\
$\beta$ & 5 & 5 & 5 \\
5 5-HT1A & 5 & 5 & 5 \\
5-HT2 & $0^{*}$ & $0^{*}$ & 5 \\
5-HT3 & 5 & 5 & 5 \\
Opioid & & & \\
Antagonist & 1000 & 100 & 10 \\
\hline mu: naloxone & $0^{*}$ & 5 & 5 \\
delta: ICI 174864 & 5 & 5 & 5 \\
keppa: nor-binaltorphimine & $0^{*}$ & 5 & 5 \\
(Control) PS & & 5 &
\end{tabular}

A group of five mice were injected with each antagonist, and also treated with $100 \mu \mathrm{g} /$ $\mathrm{kg}$ of PPHT 20 minutes after the injection.

$* p=0.0396<0.05$ compared to the control (Fisher's exact probability test).

situations in which the mice are (Masuda et al. 1996), the impairment of the fall-down in cliff avoidance reaction may be related with the 
TABLE 5. Effects of antagonists on the slipdown behavior induced by 5-HT2 agonist DOI

\begin{tabular}{lccc}
\hline \multirow{2}{*}{ Antagonist } & \multicolumn{3}{c}{$\begin{array}{c}\text { Mice showing the ship-down } \\
\text { Dose }(\mu \mathrm{g} / \mathrm{kg})\end{array}$} \\
\cline { 2 - 4 } & 100 & 10 & 1 \\
\hline $\mathrm{D}_{1}$ & $0^{*}$ & 5 & 5 \\
$\mathrm{D}_{2}$ & 5 & 5 & 5 \\
$\alpha_{1}$ & 5 & 5 & 5 \\
$\alpha_{2}$ & $0^{*}$ & $0^{*}$ & 5 \\
$\beta$ & 5 & 5 & 5 \\
5-HT1A & $0^{*}$ & 5 & 5 \\
5-HT3 & $0^{*}$ & 5 & 5 \\
Opioid & & & \\
Antagonist & 1000 & 100 & 10 \\
\hline mu & $0^{*}$ & 5 & 5 \\
delta & $0^{*}$ & $0^{*}$ & 5 \\
kappa & 5 & 5 & 5 \\
(Control) PS & & 5 & \\
\hline
\end{tabular}

A group of five mice were injected with each antagonist, and also treated with $100 \mu \mathrm{g} /$ $\mathrm{kg}$ of DOI 20 minutes after the injection.

${ }^{*} p=0.0396<0.05$ compared to the control (Fisher's exact probability test).

width of the place in which the mice were. Finally, the slip-down of mice treated with MAP may reflect the anxiety in narrow space.

Pharmacologically, the present findings indicate that the slip-down was induced via two pathways, the $\mathrm{D}_{2}$ and 5-HT2 receptor stimulations. The D2 pathway stimulated opioid mu and kappa receptor activities via $\mathrm{D}_{1}, \alpha_{2}$ and 5 -HT2 receptor activities, and the 5-HT2 pathway stimulated opioid mu and delta activities via $\mathrm{D}_{1}, \alpha_{2}, 5$-HT1A and 5-HT3 receptor activities. It looks that $\mathrm{D}_{1}$ and $\alpha_{2}$ receptor activities regulated opioid $\mathrm{mu}$ receptor activities and 5 -HT receptor activities regulated kappa and delta receptor activities. In fact, dopamine stimulates opioid mu receptor activity (Cabocho et al. 1991), and $\alpha_{2}$-adrenoceptor activity stimulates opioid mu and kappa receptor activities (Schreiber et al. 2002). As the slipdown induced by morphine is affected by naloxone treatment (Hui and Roberts 1975), the slip- down induced by MAP may be mainly driven with the opioid mu receptor activity. Otherwise, 5-HT activities temporally induce anxiety under dopamine receptor activities (Belzung et al. 2001). The anxiety may furthermore stimulate the slip-down via the other opioid receptor activities. Relations of 5-HT activities and opioid receptor activities, however, have not been clear.

Not only morphine but also MAP sometimes induces various psychotic symptoms on humans. Lately, it was reported that $\mathrm{D}_{2}$ and 5-HT2 receptor activities have a relation to MAP psychosis (Iyo et al. 1993). These and the present findings suggest that some mechanisms of MAP psychosis are common to those of morphine psychosis. Although it is unclear which symptom of the patients corresponds to the slip-down of mice, the slip-down may be an interesting method examining the common mechanisms of the psychoses.

\section{References}

Belzung, C., Le Guisquet, A.M., Barreau, S. \& Calatayud, F. (2001) An investigation of the mechanisms responsible for acute fluoetineinduced anxiogenic-like effects in mice. Behav. Pharmacol., 12, 151-162.

Cabocho, J., Rogard, M. \& Besson, M.J. (1991) Comparative development of D1-dopamine and mu opiate receptors in normal and in 6-hydroxydopamine-lesioned neonatal rat striatum: dopaminergic fibers regulate $\mathrm{mu}$ but not $\mathrm{D}_{1}$ receptor distribution. Rain Res. Dev. Brain Res., 15, 111-122.

Hirabayashi, M., Saito, T. \& Tadokoro, S. (1991) Differential sensitization to ambulationincreasing effect of methamphetamine after repeated administration to mice in activity cages of different sizes. Jpn. J. Pharmacol., 57, 91-97.

Hui, K.S. \& Roberts, M.B. (1975) An improved implantation pellet for rapid induction of morphine dependence in mice. J. Pharmacol., 27, 569-573.

Iyo, M., Nishio, M., Itoh, T., Fukuda, H., Suzuki, K., Yamasaki, T., Fukui, S. \& Tateno, Y. (1993) Dopamine $\mathrm{D}_{2}$ and serotonin $\mathrm{S}_{2}$ receptors in 
susceptibility to methamphetamine psychosis detected by positron emission tomography. Psychiatry Res., 50, 217-231.

Masuda, Y., Mastuda, Y., Kondoh, M., Shimizu, T. \& Hishikawa, Y. (1996) A quantity of stereotyped behavior of ddY mice induced by lowdose methamphetamine. Exp. Anim., 45, 279-281.

Schreiber, S., Bleich, A. \& Pick, C.G. (2002) Venlafaxine and mirtazapine: different mecha- nisms of antidepressant action, common opioid-mediated antinociceptive effects - a possible opioid involvement in severe depression? J. Mol., Nerosci., 18, 143-149.

Yoshida, S., Numachi, Y., Matsuoka, H. \& Sato, M. (2000) The absence of impairment of cliff avoidance reaction induced by subchronic methamphetamine treatment in inbred strains of mice. Tohoku J. Exp. Med., 190, 205-212. 